Teosofia: Indonesian Journal of Islamic Mysticism, Vol. 11, No. 1, 2021, pp. 89-110

e-ISSN: 2540-8186; p-ISSN: 2302-8017

DOI: $10.21580 /$ tos.v10i1.9190

\title{
SIR WILLIAM JONES (1746-1794) AND THE EARLY ORIENTALIST DISCOURSE ON SUFISM
}

\author{
Ahmad Munji \\ Marmara Üniversitesi Istanbul, Turkey \\ Corresponding Author: amunji87@yahoo.co.id \\ Hasyim Muhammad \\ Walisongo State Islamic University Semarang, Indonesia \\ hasyimmuhammad@walisongo.ac.id
}

Article history: Received: 5 November 2020; Accepted: 10 March 2021; Published: 27 April 2021

\begin{abstract}
:
Many theories have been proposed to discuss Sufism in terms of its linguistic origins and its role in spiritual knowledge, its concepts and ideas, and cultural influences. Both Muslim and orientalist scholars have offered opposing views on the beginnings of Sufism. Unfortunately, Western orientalists were the first to research this topic, and their ideas greatly influenced later scholars. This study examines how early British orientalists, particularly Sir William Jones, approached the study of Sufism. Jones represents the early development of British orientalism, which started in the form of personal travel accounts long before orientalist societies were established to support them. Only the later 'experts on the Orient' created scholarly circles that followed a more objective and systematic approach to studying Muslim cultures, yet often persisted in the erroneous claim that Sufism was an external and foreign element in Islamic culture.
\end{abstract}

Keywords: Sufism; Islamic Mysticism; British Orientalist; Sir William Jones

\section{A. Introduction}

7 he 16th century marked the beginning of English orientalism. English entrepreneurs and travelers ventured into the 'Orient' and returned home to write about their experiences in the exotic and unknown parts of the world. Most of these English travelers were, of course, not professional scholars and had their own personal motives to venture into the East, some of them involved in trade, some of them were travelers, and others were Christian missionaries who wanted to learn about Muslim language, culture, and society to proselytize the Christian faith. ${ }^{1}$ These

1 Süleyman Derin, İnggiliz Oryantalizmi ve Tasavvuf(Istanbul: Küre Yayınları, 2006), 41-48. 
travelers or visitors wrote various discourses on the Muslim world, such as travel accounts, histories, and general descriptions of geographies and local mores. They depicted the political and religious life in Muslim lands as well as the traditions, beliefs, and customs of its people and offered their own (often unqualified) commentary. ${ }^{2}$ The academic study of Sufism in Western scholarship, however, has its origin foremost in need of European representatives and trade officials to better understand the religion, culture, and beliefs of the Muslim, Hindu, and Sikh people they traded with. ${ }^{3}$

Right from the start, the number of English travelers was significantly larger than that of other European travelers. First, England was a maritime power and owned an ever-increasing fleet of armored trade vessels. This allowed the English to challenge their Spanish and Portuguese rivals, who had already installed themselves in many distant ports and entertained a lucrative trade in Africa and Asia. Second, Pope Pius V had excommunicated the Protestant queen Elizabeth I in 1570. She and her advisors saw it fit to seek commercial relations with Muslim powers in North Africa and the Ottomans. England succeeded in establishing lucrative and mutually beneficial trade relations with several Muslim powers, notably the Ottomans. ${ }^{4}$ These two factors are the two most significant reasons why the English had greater knowledge and experience in dealing with Muslim countries than others. ${ }^{5}$

As England's trade relations with the Muslim world were slowly being established in the 16th century, so did the number of English travelers who visited the 'Orient' and began writing about what they saw in their travel notes. These works, through time, began to provide some information on the far-away Muslim world. ${ }^{6}$ Since they had no missionary motives and were not intent on disparaging Islam as a religion, the writers of these travel accounts did not automatically label Islam's norms, customs, and traditions as 'deviant'. However, misconceptions and prejudiced views were still the order. The more English adventurers were returning home with their stories, the more works were published, and the English public could not get enough of these new tales from Arabia, Turkey, and Persia. Thus, the Western scholarship could finally break away from relying on the controversial accounts written by belligerent

2 Anna Kalinowska, "An Englishman In-between Two Worlds: Robert Bargrave's Travel through East-Central Europe, 1652-1653," Studia Historyczne 61, no. 4 (244) (June 1, 2021): 45-54, https://doi.org/10.12797/SH.61.2018.04.03.

3 Atif Khalil and Shiraz Sheikh, "Sufism in Western Historiography: A Brief Overview," Philosophy East and West 66, no. 1 (2016): 194-217, https://doi.org/10.1353/pew.2016.0022.

4 Kenneth Parker, "Introduction," in Early Modern Tales of Orient, A Critical Anthology (London: Routledge, 1999), 9.

5 Süleyman Derin, “İngiliz Oryantalistlerinin Tasavvuf Araştırmalarına Katkıları," Türkiye Araştırmaları Literatür Dergisi 16, no. 21-32 (2018): 177-96.

6 Sari J. Nasir, The Arabs and the English (London: Longman Group, 1976), 5. 
Christian churchmen many centuries ago. In the 17 th century alone, nearly 200 titles were published that dealt with the Muslim world. ${ }^{7}$

Among those travel records that mention Sufism or Sufi orders is Nicolas de Nicolay's "Discours et Histoire Veritable Des Navigations, Peregrinations et Voyages Faicts en la Turquie" (The Navigations, Travels, and Journeys Made to Turkey) (1576), translated from French into English by Thomas Washington under the title The Navigation into Turkiye in 1585. Although not authored by a scholar, Washington's decision to translate the work and publish it in England demonstrates the importance of this work, and the interest it evoked at the time. Nicolay explained that the name 'Sufism' originated from the words suf (wool) and 'sophy' while referring to his followers as Sufiyun (Arabic: șū fi yūn). Thus, he may have been the first orientalist to discuss the origins of this term in the West. ${ }^{8}$ It is also possible that his work and the first discussion of Sufism prompted later orientalists to adopt his usage of the term.

However, Nicolay did not have nice things to say about the Sufis and considered them as inherently 'evil.' Nicolay's negative view of Sufism may be reflected in one of his printed illustrations, Deruisio Religioso Turco (The Devout Turk). The Sufi (or rather a Sufi dervish) is represented as a half-naked man who cuts into his arm with a knife. ${ }^{9}$ Nicolay's illustrations were depictions of actual people he had seen while a guest of the Ottoman imperial court in Istanbul. The person depicted was probably a member of the Kalandar order, a local tañqa that even the Ottomans themselves considered as deviant. ${ }^{10}$ However, Nicolay's description of Sufi orders and Sufi practices was grossly misleading and too eclectic to accurately represent Sufism in Ottoman society. His Travels were, after all, a very subjective account of his experience and not a scholarly treatise. In short, like all travel accounts, it was meant more to entertain and evoke the imagination of its readers (and thus push up sales) rather than duly inform and educate them.

Another early work that mentions Sufism is The Travels of Certaine Englishmen .$^{11}$ (1609) by William Biddulph (fl. 1600-1612). He was a Protestant clergyman who traveled from Aleppo to Palestine in the early 17th century and later published an

7 Yücel Bulut, "Oryantalizmin Tarihsel Gelişimi Üzerine Bazı Değerlendirmeler," Marife Dergisi 3, no. 2 (2002): 13-38.

8 Arthur John Arberry, An Introduction to the History of Sufism (London: Orient Longman, 1942), 7; Nicolas de Nicholay, The Navigations into Turkiye (Amsterdam: Theatrum Orbis, 1968), 105.

9 Nicholay, The Navigations into Turkiye, 106.

10 Haci Sağlık, "Kalenderî Bir Sûfî Olarak Baba Tâhirê Uryân," E-Şarkiyat 10, no. 2 (May 30, 2018): 708-23, https://doi.org/10.26791/sarkiat.368830.

11 The full title is The travels of certaine Englishmen into Africa, Asia, Troy, Bythinia, Thracia, and to the Blacke Sea and into Syria, Cilicia, Pisidia, Mesopotamia, Damascus, Canaan, Galile, Samaria, Iudea, Palestina, Ierusalem, Iericho, and to the Red Sea: and to sundry other places. Begunne in the yeare of iubile 1600. and by some of them finished in this yeere 1608. The others not yet returned. Very profitable to the help of trauellers, and no lesse delightfull to all persons who take pleasure to heare of the manners, gouernement, religion, and customes of forraine and heathen countries.

Teosofia: Indonesian Journal of Islamic Mysticism, Vol. 10, No. 1, 2021 
account of his experiences. ${ }^{12}$ Between 1600 and 1608, Biddulph traveled to Sicily, North Africa, the Red Sea, Palestine, and Persia and described what he had seen in letters to his brother, Bezalel. His travel records consist of twenty such letters published in London in 1609 under the title The Travels of Certaine Englishmen. Biddulph had no particular interest in Islam or a desire to understand it, and, therefore, he portrayed the religion of Islam mostly by capitalizing on the negative and cliché images which were prevalent in Western polemic writings. ${ }^{13}$

Like most Christian commentators of his time, Biddulph conveyed false information about Islam in general and Sufism in particular. In his view, all Muslim people were essentially ignorant and misguided, and they considered every fraudster and madman a saint (wa/i). Once the people had recognized a madman as a saint, he was at complete liberty to do as he pleased, even take their property and hurt them; otherwise, he would cause them great misfortune and send God's wrath upon them, they feared. When these madmen died, Biddulph writes, the other Muslims would build majestic tombs for them. He added that this kind of fanaticism was most rife in Syria. ${ }^{14}$ Like many Western travelers before him, he seems to have confused the Indian dervish or faqi $r$ with the regular member of a Sufi order. Biddulph draws a saint's image as lazy, deranged, and homeless based on his assumption that all Sufis were frauds and devoid of morals.

Biddulph's distorted views can be easily explained when understanding his underlying motive for badmouthing the Muslims in this way. One of his letters opens with the following words:

"For hereby all men see how God blessed our country above other, and be stirred up to thankfulness. Hereby subjects may learn to love, honor, and obey their good and gracious king when they shall read of the tyrannous government of other countries, and the merciful government of theirs. Hereby readers may learn to love and reverence their pastors, and to thank God for the inestimable benefit of the preaching of the Word [Bible] amongst them when they shall read in what blindness and palpable ignorance other nations live, not knowing the right hand from the left in matters that concern the kingdom of heaven, and yet reverence and honor their blind guides and superstitious churchmen like angles, and provide for their maintenance royally." 15

12 Ummi Nadhirah Rosli and Noritah Omar, "References of Sexuality in Relation to the Prophet Muhammad (PBUH) in 17th-19th Century: Selected French and English Orientalist Travelogues," Arab World English Journal For Translation and Literary Studies 1, no. 4 (October 15, 2017): 68-82, https://doi.org/10.24093/awejtls/vol1no4.5.

13 Ahmad Gholi, "Reiteration of Prophet Muhammad's Myths in Biddulph and Cartwright's Travelogues," Mediterranean Journal of Social Sciences 7, no. 1 (January 5, 2016): 251-58, https://doi.org/10.5901/mjss.2016.v7n1s1p251.

14 William Biddulph, "The Travels of Certain Englishmen," in Early Modern Tales of Orient, ed. Kenneth Parker (London, New York: Routledge, 1999), 92-96.

15 Biddulph, "The Travels of Certain Englishmen,"... 85. 
Undoubtedly, Biddulph wanted to strengthen his fellow countrymen's belief in the Protestant faith and the legitimacy of the Crown. His clear message is that the English people were fort unate to be true Christians (i.e., Protestants) and thus far more civilized than the 'Turks'. Given this somewhat polemical motivation, we cannot expect him to convey accurate information and give an objective account of Islam or the Muslim world.

Another English traveler and author who misrepresented Islam and Sufism was William Lithgow (died ca. 1646). Lithgow is one of the most unusual characters in all the literature, a world traveler whose work The Total Discourse of The Rare Adventures \& Painefull Peregrinations of Long Nineteene Yeares Travayles from Scotland to the Most Famous Kingdomes in Europe, Asia, and Africa was first published in $1632 .{ }^{16}$ Compared to Nicolaye and Biddulph, Lithgow gives the most frightful and appalling descriptions of Muslim saints. In his account, Muslim saints are people who have returned from the pilgrimage with their eyes gouged out. They spend the rest of their life without their sight so that they no longer have to see the evils of the world. According to his testimony, Lithgow witnessed such blind men returning from their pilgrimage who were treated as holy men by the local Muslims who honored them and served them. ${ }^{17}$ His description is very astounding to the Muslim reader today, especially since Islam specifically prohibits any form of self-harm. The same is true for Sufi teachings, as reflected in the Sufi literature. It is common knowledge that it is not permissible to inflict bodily harm on oneself to avoid sinful acts and certainly not to reach a higher spiritual level.

The fourth English traveler and writer on Islam and Sufism to be mentioned in this context is Joseph Pitts (1663-1735). He was taken prisoner by Barbary pirates at the age of fourteen in Algiers in 1678 and spent years in servitude to his Muslim masters before he managed to escape between 1693 and 1694. After being freed from captivity and returned to England, Pitts claimed that he had converted to Islam only to escape certain slavery and death. ${ }^{18}$ As a Muslim convert, Pitts traveled to Mecca, Medina, and Jeddah together with his master in 1685 and was the first European to describe the hajj and give detailed descriptions of Muslim customs and laws. Among his notes is the drawing of the $\mathrm{Ka}^{\prime}$ aba that was published together with his book in 1704. ${ }^{19}$ Pitts described the Sufis as a group of wandering people who wore white sheepskins, carried a long staff in their hand, and had prayer beads hanging around

16 Alan Riach, "Odd Fellows: Alan Riach Examines the Colorful Work of William Lithgow and Thomas Urquhart," The National, April 7, 2017, 2.

17 Biddulph, "The Travels of Certain Englishmen,"... 154.

18 At that time Christian captives were given the choice of either converting to Islam or be sold as slaves, and Pitts chose to convert to Islam.

19 Sorin Ciutacu, "Arabia in the Early Modern European Mind. Representations of Arabia in Early Modern European Maps," Analele Universităţii de Vest Din Timişoara. Seria Ştiinţe Filologice, no. 57 (2019): 139-44. 
their necks. Pitts likened them to Christian priests since priests lived in orders, wore a distinctive habit, and owned no property. The fact that the wandering Sufism depended for their daily meals on the generosity of others also made them similar to monks who relied on pious donations. ${ }^{20}$

Pitts probably met some Sufis while performing the pilgrimage with his master or on their way from Cairo to Alexandria. What gives credibility to his account is that the garments worn by the Turkish pilgrims at the same were exactly as described by Pitts. ${ }^{21} \mathrm{He}$ later used the similarities between Sufis and Christian monks to argue that Sufi practices were originally based on Christian practices, and this argument would then be borrowed by many orientalists when discussing the influence of Christianity on Sufism.

As explained earlier, the European writers of travel notes often mixed up facts and were primarily based on the authors' imagination rather than on true observation and facts. This is mainly the result of their background (they were not learned scholars), and most were not seriously interested in the cultures of the places they visited. Unlike English trade officials stationed in India in the 18th century, they did not spend years immersing themselves in the study of local languages, culture, and history. They did not become experts in their fields. In essence, these early travelers just wanted to write exciting stories that would captivate their readers, sell really well, and make them rich and famous.

The English travelers frequently used the words faqir and dervish to describe the Sufis. Indeed, faqīr is used in both Arabic and Persian to describe wandering saints who perform miracles, but European travelers did not use the word faqi $r$ in this sense but understood it in its literal meaning of 'destitute' and 'beggar'. ${ }^{22}$ These early travelers mentioned the Sufis but provided only scant information about them, describing them as beggars, simpletons, or lunatics. Thus, viewed from a historical perspective, Western attitudes towards Islam and Sufism were expressively negative and based on derogative stereotypes. In short, they rejected the notion that the Muslim world was civilized at all. ${ }^{23}$

Thankfully, these false and misleading views were soon criticized and corrected by professional orientalists. As pointed out by Simon Ockley (1678-1720), the early English travelers had been woefully ignorant of the places and the peoples they had

20 Sir William Foster, An Account by Joseph Pitts of His Journey from Algiers to Mecca and Medina and Back (United Kingdom: Millwood, 1990), 27.

21 Serkan Demir, "Akdeniz'de Korsanlar Ve Esirler Bağlamında Joseph Pitts Ve Esâretnâmesi” (Hacattepe Üniversitesi, 2020), 144, http://hdl.handle.net/11655/22576.

22 Carl W. Ernst, Sufism: An Introduction to the Mystical Tradition of Islam (Boulder, Colorado: Shambhala Publication, 1997), 1-8.

23 Algis Uždavinys, "Sufism in the Light of Orientalism," Acta Orientalia Vilnensia 6, no. 2 (January 1, 2005): 14-125, https://doi.org/10.15388/AOV.2005.0.3966. 
visited and known very little of the local cultures and languages. He wrote, "They take incomplete information from Muslims and present it to us in a more absurd form."24

In the coming decades, British orientalism established itself as an academic discipline in its own right. This development is indicated in the fact that its approach to the study of the Orient became more systematic, with its own scholarly institutions and research carried out by a group of often extremely gifted and talented academicians, among them being William Jones. The following sections will discuss his accomplishments in more detail, including his career and views on Sufism. Jones represents early British orientalism at its best by founding the Royal Asiatic Society of Bengal in 1784. Jones is widely regarded as a pioneer in orientalist studies. As a British East India Company official, ${ }^{25}$ he changed the direction of orientalism from Christian polemics to the serious study and recognition of the local cultures (that included Hindus, Muslims, Christians, and Sikhs) in its efforts to 'direct the people under its rule'. ${ }^{26}$ Moreover, unlike his predecessors, Jones was the first orientalist who discussed Sufism and Sufi practices in a respectful and erudite manner.

\section{B. Sir William Jones (1746-1794)}

William Jones is one of the most important names in the line of eminent British orientalists. The prominent orientalist Arthur John Arberry (1905-1969) introduced Jones as the founder of British orientalism, even though orientalist study had been there long before him. The reason is, while other orientalists had worked individually, Jones laid the foundations of orientalist study as a respectable branch of scholarly inquiry and research. ${ }^{27}$ Arberry is not exaggerating; Jones occupies an important place among the line of British orientalists who prepared the field for future generations. ${ }^{28}$

Born in London on 28 September 1746, William Jones grew up under the care of his mother; his father had died when William was only three years old. His interest in the East soon became evident when he began studying Arabic in high school. As a student at Oxford University since 1764, he took up Western languages but continued to follow his interest in Arabic and even found himself an Arabic tutor from Syria. ${ }^{29}$ Apart from Arabic, Jones also studied Persian and other Eastern languages. It was soon

24 Nasir, The Arabs and the English, 38.

25 The East India Company effectively ruled parts of India, and the British Crown took over only after the Mutiny in 1859.

26 Ahmet Davutoğlu, "Batıdaki İslam Çalışmaları Üzerine," Marife 3, no. 2 (2002): 39-52, https://doi.org/10.5281/zenodo.3343235.

27 Arthur John Arberry, Oriental Essays, Portraits of Seven Scholars (London: Curzon Press, 1960), 49.

28 Carl W. Ernst, "Commentary on Part I: Ambiguities and Ironic Reversals in the Categorization of Sufism," in Modern Sufis and the State, ed. Katherine Pratt Ewing and Rosemary R. Corbett (West Sussex: Columbia University Press, 2019), 73-78, https://doi.org/10.7312/ewin19574-007.

29 Bernard Lewis, British Contribution to Arabic Studies (Oxford: Oxford University Press, 1961), 18. 
becoming apparent that Jones was a young philologist in the making: he was already fluent in French, Italian, Spanish, Portuguese, Greek, and Latin. ${ }^{30}$

Jones' expertise in linguistics spread throughout Britain and even abroad. Thanks to this fame, Jones was asked by King Christian VII of Denmark to translate the manuscript of Astarabadi's Tãnīkh-i Nã din̄ from Persian into French, which he completed in 1770 (Histoire de Nader Chah) at the age of 24. The book was published in the same year and was the first work of orientalism that Jones had authored, but certainly not the last. ${ }^{31}$ In the following year, Jones presented his Grammar of the Persian Language, and soon after he was elected a Fellow of the prestigious Royal Society of London (FRS). ${ }^{32}$

Jones' aptitude in linguistics, however, does not mean that he did not excel in other fields. He authored a book of the law (Essay on The Law of Bailments) published in 1781, which would become a well-regarded work in legal studies. With his success in law and his interest in Eastern languages and cultures, he was appointed a judge in the high court of Calcutta in 1783. Naturally, his new assignment offered Jones further opportunity to pursue his philological and cultural interests. While on his way to India, he purposefully outlined his agenda:

"Objects of inquiry during my residence in Asia: The laws of the Hindus and Muhammadans [Muslims], modern politics and geography of Hindustan, the best mode of governing Bengal, Arithmetic and geometry, and mixed sciences of the Asiatics, Medicine, Chemistry ...." 33

Jones succeeded in realizing most of the points on this agenda. His correspondence with his friends, especially Earl Spencer (1758-1834), gives us an idea of how seriously he was invested in his academic work. For example, in his letter to Earl Spencer, he states his ambition to become an acknowledged authority in orientalist studies: "My only wish is to be the most respected European person who knows India better than anyone. For me, just one day not getting any new information about Indian people or their plants is a big loss." 34 In another letter to Earl Spencer dated 20 February 1791 he wrote, "In one day I work harder than two people". ${ }^{35}$

Upon arrival in India, Jones first translated the Manusmriti (a major work of ancient Indian philosophy) from Sanskrit into English. It was published after his death

30 Lord Dundonald et al., Famous Men, Being Biographical Sketches from Chamber's Miscellany (London: Chamber's Miscallany, 1892), 2.

31 William Jones, "Histoire de Nader Chah," in The Works of Sir William Jones, ed. Lord Teignmouth (Cambridge: Cambridge University $\quad$ Press, 1807), 35, https://doi.org/10.1017/CBO9781139507004.001.

32 The Royal Society is an association of scientists founded in 1660 to advance science. This organization had the support of the then king of British, Charles II in 1662.

33 Arberry, Oriental Essays, Portraits of Seven Scholars,... 62.

34 Arberry, Oriental Essays, Portraits of Seven Scholars,... 66.

35 Arberry, Oriental Essays, Portraits of Seven Scholars,... 70. 
in 1796 under the title Institutes of Hindu Law: Or, the Ordinances of Manu. In addition, Jones also continued to study the Arabic language. His goal of becoming thoroughly acquainted with the two languages, Hindustani and Arabic, had to do with his official duties. He wrote: "I am now helping the courts by learning Indian and Arabic. Thus, Hindu and Muslim judges do not force me to accept their false law". ${ }^{36}$ In the field of Islamic law, Jones translated a work on inheritance law known as Kitā b alFarā'id al-Sirājlya (The Sirajite Book of Inheritance Laws) into English which was published in 1792. ${ }^{37}$ Presumably, the issue of Muslim inheritance was on the agenda of the British courts in India at the time, which prompted Jones to translate a major work on inheritance law. This clearly shows that he was genuinely interested in studying Islamic law and not prejudiced against it. Thus, his attitude reflects most English Company officials stationed in India in the 18th century, who had the utmost respect for local cultures and traditions and a genuine interest in them. This applied to Hindu culture as well as Muslim culture.

Shortly after his arrival in India on 15 January 1784, Jones established the Royal Asiatic Society of Bengal, a scholarly institution like the Royal Society in London but devoted to the academic study of oriental cultures. Jones was certainly inspired by the Royal Society, of which he himself was a distinguished Fellow. He was convinced of the necessity of an organized association for the advancement of oriental studies. ${ }^{38}$ Thus, orientalist study that had hitherto been carried out by (rather eccentric) individuals with various backgrounds and (often questionable) levels of expertise was institutionalized, standardized, and transformed into proper scholarly discourse. Jones wrote to friends about his idea of establishing the Royal Asiatic Society of Bengal, and his proposal received support from no less than thirty European officials serving in India. On 15 January 1784, eminent persons such as presiding judge Hyde, John Carnac, Henry Vansittart, John Shore, Charles Wilkins, Francis Gladwin, and Jonathan Duncan met under the leadership of Sir Robert Chambers in the tribunal chamber of the High Court of Calcutta and formally recognized the establishment of the Society.

As can be understood from the list of names, that day, almost every high-ranking British official serving in India supported Jones's ambitious plan. According to Arberry, the formation of the Asiatic Society by Jones in 1784 was a crucial moment in the history of orientalism. In his view, it was a big step forward, for here were found the first beginnings of a scientific movement that was destined to spread to all parts of the world. ${ }^{39}$

36 Lord Dundonald et al., Famous Men, Being Biographical Sketches from Chamber's Miscellany, 4.

37 William Jones, Al-Sirajiyah or the Muhammadan Law of Inheritance, ed. Almeric Rumsey (London: Law Bookseller and Publisher, 1869). This work was later republished in 1977.

38 Saiyed Samirmiya Amirmiya, "Foundation of the Asiatic Society and the Discoveries of Cultural and Literary History of India," International Journal of Research and Analytical Reviews 6, no. 1 (2019): 139-41.

39 Owen Watkin, “Sir William Jones (1746-1794) and Islamic Studies” (University of Wales, 2013), 55.

Teosofia: Indonesian Journal of Islamic Mysticism, Vol. 10, No. 1, 2021 
Sir Jones headed the Royal Asiatic Society of Bengal until the end of his life in 1794. His pioneering act of founding the Royal Asiatic Society ushered into a new era of orientalism. He was among the first European scholars to argue that the history of mankind can be traced back to the ancient civilizations in the East (and not ancient Greece) and that a complete history of humankind cannot be written without a full understanding of the ancient Eastern civilizations that had existed long before the idea of Europe was even conceived. Among his many contributions is the concept of phonetic transcription. Phonetic transcription systems are still used today to help translate works written in non-European scripts, such as Hindi, Urdu, Arabic, and Persian, into Latin script.

The Persian classics published by Sir Jones while in India were also well received by British academicians. One of his first projects in Persian literature was the translation of Abdullah Hatifi's (died 1521) Layli o Majnun. ${ }^{40}$ Jones reveals the reason for translating this literary masterpiece as follows:

"The incorrectness of modern Arabian and Persian books is truly deplorable:
nothing can preserve them in any degree of accuracy but the art of printing; and, if
Asiatick literature should ever be general, it must diffuse itself, as Greek learning
was diffused in Italy after the taking of Constantinople, by mere impressions of
the best manuscripts. But no printer could engage in so expensive a business
without the patronage and the purse of monarch or states or societies of wealthy
individuals, or at least without a large public subscription. There are printers in
Bengal, who, if there were duly encouraged, would give us editions of Hafiz and
Sadi, or perhaps, of Nizami and Firdausi."

Jones' attention to Sufism works is equally important. He believed that by publishing works of Sufism, Western society could usher into a new period of intellectual (and spiritual) revival. Convinced that this step was a necessity, Jones expressed his idea as follows:

"Poetry works in Europe have long used the same symbols, images, and stories, there is almost nothing new in them. If in our library there are many books from Asia which are translated, published with explanations, and the language is taught in our universities, as in other disciplines, our literature will get new symbols, metaphors, and parables. If such compositions are revealed and our academicians explain them, our poets may well imitate them in the future." ${ }^{42}$

40 This work is another version of Laila Majnun written by the Persian poet Nizami in Masnavi format. M. Ibrahim Yıldırım, “Abdullâh Hâtifî’nin Hayati Ve Bir Tarih Kaynaği Olarak Timurnâme'sinin Değeri," TÜRKIYYAT MECMUASI 28, no. 2 (December 18, 2018): 231-54, https://doi.org/10.18345/iuturkiyat.497592.

41 Arthur John Arberry, "Islamic Literature: Persian," in Near Eastern Culture and Society A Symposium on the Meeting of East and West, ed. T. Cuyler Youngs (Princeton: Princeton University Press, 1951), 71.

42 William Jones, "An Essay on the Poetry of the Eastern Nations," in The Works of Sir William Jones, ed. Lord Teignmouth (Cambridge: Cambridge University Press, 1807), 329-60, https://doi.org/10.1017/CBO9781139506991.024. 
Jones's words illustrate his view that Islamic culture and Sufism, with its vast literary wealth, had the power to influence Western culture. This also means that Jones thought that from the perspective of civilization, the East was far more advanced than the West in many ways. For this reason, modern research on the influence of Sufi literature and its contribution to the development of Western literature seems an interesting and worthy undertaking.

The works that Jones produced in less than thirty years had a measurable impact on the West, and his fame as an orientalist was soon spreading all across Europe. Fellow philologists and linguistics saw him as an example that is difficult to match. In a personal note he wrote to the Governor-General of Bengal (1793-1798), Baron Teignmouth, Jones claimed to speak eight languages very well, could understand eight languages with the help of a dictionary, and was fairly competent in another twelve languages. ${ }^{43}$ Jones, who made science the philosophy of life, undertook a great deal of research throughout his life. Jones' orientalist work, which he undertook with equal passion and professionalism, had to end at a relatively young age. Jones contracted a liver infection and died in Calcutta on 27 April 1794, at the age of only forty-eight. Throughout his tenure in India, Jones was highly respected and loved by the local people who gave him the Muslim name 'Salim'. After his death, two monuments were erected in his memory. The first was a statue at the University of Oxford where Sir Jones is depicted learning from three Hindu scholars. The second was a wall memorial in the crypt of St Paul's Cathedral in London.

\section{William Jones's Views on Sufism}

As discussed in the previous discussion, Jones studied Arabic and Persian extensively, especially while studying Oxford. His knowledge allowed him later to access Sufi works written in these two languages. Jones' interest in Sufism began when reading the famous Persian poet Hafiz (d. 1390). He expressed his admiration for Hafiz by translating some of his poems into English. Jones also felt he would have wasted his time in India if not learning ancient Sanskrit and studying ancient Hindu philosophy. His Hindu and Persian literature study made him aware of the similarities between Sufi and Hindu teachings and philosophy. ${ }^{44}$

According to Arberry, Jones was probably the first European scholar to discuss the similarities between Sufism and Vedic philosophy. Before Jones, most orientalists viewed Sufism as a mixture of Neoplatonic and Christian ideas. ${ }^{45}$ This misconception was challenged by Jones who argued that Sufism was influenced by Hindu and Persian

43 Arberry, Oriental Essays, Portraits of Seven Scholars,... 76.

44 Kemal Kahraman, “Jones William,” DIA (Istanbul, 2001), 582.

45 Among the early orientalists who said that Sufism was rooted in Christian values was Simon Ockley. See Simon Ockley, "Introduction," in The Improvement of Human Reason Exhibited in the Live of Hay Ibn Yaqzan (London, 1708), i. 
philosophy and included this theme in the orientalist agenda. ${ }^{46}$ Several scholars followed Jones' example in the $19^{\text {th }}$ century, such as August Tholuck (1821), Alfred von Kramer (1868), Max Horten (1912), Ignaz Goldziher (1899, 1925), and R. C. Zaehner (1969) who further explored the similarities between Sufism and Hinduism. ${ }^{47}$

Jones first compared the leading Persian works of poetry written by Jalaluddīn al-Rumi (d. 672/1273), Ḥafidh al-Shīrāzī (d. 792/1390), ${ }^{48}$ and Sa di al- Shīrāzī (d. $691 / 1292)^{49}$ with the texts of the Vedantaschool of ancient Hindu philosophy (Upanishads). However, despite his enthusiasm for Indian cultural traditions, he limited his approach to Sufism to Persian poetry. In other words, he paid great attention to Sufi poems and accepted what they contained Sufi ideas and imagery as a complete portrait of Sufi teachings. Jones thus dismissed the fact that these literary works are not classical works of Sufi thought and practice. Classical Persian poetry works have multi-layered meanings that allowed for multiple interpretations, thus reflecting the author's emotional world rather than Sufism as a whole. Also, poets like Rumi, Hafiz, and Sa'di do not necessarily represent the teachings of all Sufi masters who have contributed to the development of Sufism. Jones was therefore mistaken when he concluded that the ideas contained in these poems could be used as the foundation of a scientific study of Sufism. Furthermore, their poetry reflects the Persian mystical tradition and not a mystical tradition in Islam as a whole, especially when it comes to early Sufism. ${ }^{50}$ It seems that Jones was often carried away by his high admiration for Indian culture and was often too willing to see similarities that were not necessarily there. ${ }^{51}$

Jones understood the mystical philosophy of Sufism as defined by its universal values; the same he applied to Christian mysticism. Moreover, he considered Christian, Sufi, and Hindu mystical philosophy to be based on universal teachings and thus built on common ground. In his view, what distinguished one from another was that one was

46 William Jones, "The Sixth Discourse on the Persian," in Works, vol. iv (London, 1807), 220-21.

47 Hikmet Yaman, "İsmi Olmayan Bir Hakikatten Hakikati Olmayan Bir İsme Varan Yolculuk," Akademiar Dergisi 1, no. 1 (2016): 15-48.

48 Hafiz al-Shirazi's only work, the Divan, has been very popular in Iranian and world literature. Deniz Özen, "Sûdî’nin Hâfız-1 Şirâzî Dîvânı Şerhi: 75a-99b Varakları Arası Transkripsiyonlu Metinİnceleme" (Binali Yıldırım Üniversitesi, 2018), 5.

49 Sa'di al-Shirazi's Bustan and Gülistan influenced generations of Turkish poets and writers. See Gemze Gizem Avcıŏlu, "Sa'di Sîrâzî’nin Hayatı, Eserleri ve Türk Edebiyatındaki Yeri” (Istanbul Üniversitesi, 2018), 14.

50 Michel Sells proposed two phases of the formative period of Sufism: 1) the founding period which includes such figures as Ibrahim b. Adham (d. 778/9), Abd Allah b. al-Mubarak (d. 797), and Dhun al-Nun al-Misri (d. 860).; 2) the formative period of Sufi literatüre and begins in the middle of the tenth century. See Atif Khalil, Repentance and the Return to God: Tawba in Early Sufism (New York: Suny Press, 2018), 2.

51 Jones's major contribution as a philologist was the concept of the family of 'Indo-Germanic' languages which linked ancient Persian to the modern European languages. Jones, "The Sixth Discourse on the Persian," 220. 
the fruit of European civilization, while the other was Asian. ${ }^{52}$ The lengthy quotation he wrote from the mystical Christian writer M. Necker (1737-1794) here will serve as an example of his approach:

\begin{abstract}
"It may even be imagined, that love, the brightest ornament of our nature, love, enchanting, and sublime, is a mysterious pledge for the assurance of those hope; since love, by disengaging us from ourselves, by transporting us beyond the limits of our being, is the first step in our progress to joyful immortality; and, by affording both the nation and example of a cherished object from our fouls, may be considered as an interpreter to our hearts of something, which our intellects cannot conceive. We may seem even to hear the supreme intelligence and eternal soul of nature, give this confirmation to the spirits, which emanated from him: Go, admire a small portion of my Works, and study them; make your first trial of happiness, and learn to love him, who be slowed it; but seek not to remove the veil spread over the secret of your existence, your nat ure is composed of those divine particles, which, at an infinite distance, constitute my essence; but you would be too near me, were you permitted to penetrate the mystery of our separation a union; wait the moment ordained by my wisdom; and until that moment come, hope to approach me only by adoration and gratitude." ${ }^{53}$
\end{abstract}

Jones argued that mystical Sufism in its essence reflects universal mystical values. Thus, if the quote given above was written in Sanskrit, Persian, and Arabic and shown to followers of the respective schools and persuasions, they would assume that it was theirs and claim it as their own. Hindu and Sufi thought to share the idea that part of human nature is divine and that the universe is a manifestation of God. Furthermore, the love for God is the only true love, and the love for anyone or anything other than Him is merely an illusion. The beauty of nature and human beauty are but a reflection of God's beauty. It is the belief shared by all mystical traditions that to achieve true happiness, one must seek closeness with God and achieve this closeness through acts of obedience. From the Islamic perspective, humans can only return to their original nature through God and thus keep the primordial pledge they have given God in the eternal realm. Therefore, we must detach ourselves from the seduction of the beauty of this world and direct our attention to the source of all beauty which is God. After all, everything in the universe is nothing but a reflection of God. ${ }^{54}$

In Islamic philosophy, the concept of ' $a r a d$ (accident) is defined as "that which cannot subsist by itself but only in a substance". ${ }^{55}$ On this point, Jones commented that the Sufis were way ahead of the philosophers and had completely done away with the concept. He wrote rather condescendingly:

52 Jones, “The Sixth Discourse on the Persian,"... 209.

53 Jones, "The Sixth Discourse on the Persian,"... 220.

54 Jones, "The Sixth Discourse on the Persian,"... 220.

55 F Rahman, "A Arad," in Encyclopaedia of Islam, Second Edition, ed. P. Bearman et al. (Leiden: Brill, 2012), https://doi.org/10.1163/1573-3912.

Teosofia: Indonesian Journal of Islamic Mysticism, Vol. 10, No. 1, 2021 
"The things that idiots call essences are just reflections, only that the immortal creator constantly flashes them into our minds. However, we should not get too caught up in this reflection, but devote ourselves to God. God is in us, and we must also be in God. We must always remember the promises we made to God in the eternal realm, remembering them like beautiful music, gentle breezes, and fragrant aromas. We must distance ourselves from thinking about things that are not useful, and focus on drawing closer to God. Uniting with Him is true happiness."

Jones had learned of the primordial dialogue between the human souls (arwāh) and God in the eternal realm, as found in the famous Qur'anic phrase of 'a-lastu birabbikum (Am I not your God?) found in Sūra al-A'rāf (7:172). This idea plays a central role in Sufi thought. Jones was aware that this dialogue is a popular theme in Sufi literature. When God gathered the created souls and asked them to confirm that He was their God (and Creator), the souls replied in unison, 'balā' (yes, indeed). Jones understood this reference correctly as it appeared in Persian poetry sources and stated that the affirmative 'yes, indeed' would continue to resonate in the mystical works of Islamic poetry. ${ }^{56}$

Jones understood the Qur'anic theme of the primordial dialogue between God and the human souls as being adopted and further developed by the Sufis. Thankfully, Jones attributed this doctrine, not to Persian mysticism alone but Islamic mysticism in the broader sense. When Jones came across the same theme in Turkish poetry, he concluded that the Turkish poets must have adopted it from the Persian poets as part of a cultural assimilation process. However, Jones was convinced that only the Persian could truly 'think mystically'.

Jones also tried to analyze the metaphorical words of the beauty of God contained in Sufi poetry. The beauty of God as expressed in the verses of Rumi and Hafiz often provoked Jones' curiosity, and he immediately went on to decide whether an image was used as a trope (majā $z$ ) or in its true meaning (haquqa). The following poem written by Hafiz (d. 1390) he categorized as conveying a metaphorical meaning:

In eternity without beginning, a ray of the beauty began to gleam....

On that day the cheek sparkled even under the veil.....

From the moment when I heard the divine sentence, I have breathed into man a portion of my spirit, I was assured that we were His and He ours.

Where are the glade findings of union with thee that I may abandon all desire of life? ? $^{7}$

In the stanza above it is clear that Hafiz describes the bond of love that binds man to God, an indirect reference to the Qur' anic notion of 'a-lastu. Jones also found an example of the trope in one of Hafiz's poems that describe worldly beauty:

56 Jones, “The Sixth Discourse on the Persian,"... 221.

57 Jones, "The Sixth Discourse on the Persian,"... 225. 
May the hand never shake, which gathered the grapes

May the foot never slips, which pressed them

That poignant liquor, which the zealot calls the mother of sins, is pleasanter and sweeter to me than the kisses of a maiden. ${ }^{58}$

Jones criticized the puritanism of some of Hafiz's devotees, who argued that all his references to wine and women were purely metaphorical. However, Hafiz himself had never been or claimed to be a purist and, therefore, it can be safely assumed that he was referring to actual wine and actual women, albeit without losing sight of the bigger (metaphorical) picture. For example, the state of drunkenness can be used as a symbol of worship and devotion; sleep can mean reflecting upon the beauty of God; fragrance can be understood as the promise of God's love; kiss and embrace can symbolize intimacy with God and His revealing of some of His secrets; and unconsciousness the state of the believer when experiencing the touch of the Divine. However, Jones' viewed these interpretations as being overly forced and based on necessity rather than choice. Hafiz is highly esteemed in many Muslim countries, especially in Iran, where it is still common to recite his poetry, especially at cultural events. The general public is highly familiar with his verses and does not take offense in his often romantic imagery. Jones also defended Hafiz from accusations that he was in fact a disbeliever; he never meant to say ' $/ \bar{a} d i n$ ' (no religion) to accommodate those who rejected religion or make fun of it. ${ }^{59}$

Jones argued that the task of distinguishing the divine and human dimensions of Hafiz's poetry largely depended on interpretation. For example, he quoted Hafiz's poems praising the virtues of women and grapes, which can be interpreted in many ways. Another Persian mystical poet that caught his attention was Mevlana Rumi (d. 1273). He translated the first twenty stanzas of Rumi's famous Masnavi into English, which was the first English translation of its kind. ${ }^{60}$

However, Jones' knowledge of Persian poetry was not limited to the great names; he was also acquainted with other mystical poets such as Șā'ib al-Tabrīzī (d. 1677), 'Urfi al-Shīrāzī (d. 1590), Jami (d. 1492), and Hazīn al-Lāhījī (d.1766). He also knew the Ottoman Mesihi of Pristina (d. 1512). ${ }^{61}$ Jones' main approach to the study of Sufism was through mystical Persian poetry. This, however, also means that Jones was not familiar with classic Sufi works written in prose.

One of the weaknesses of the orientalists of his time was that their choice was rather eclectic and did not include going back to the primary source texts of Sufism.

58 Jones, "The Sixth Discourse on the Persian,”... 226.

59 Jones, "The Sixth Discourse on the Persian,"... 223.

60 See, Jonathan Lawrence, "Building a Library: The Arabic and Persian Manuscript Collection of Sir William Jones," Journal of the Royal Asiatic Society 31, no. 1 (January 9, 2021): 1-70, https://doi.org/10.1017/S1356186320000607.

61 Garland Cannon, The Life, and Mind of Oriental Jones (Cambridge: Cambridge University Press, 1991), 338. 
They often relied too heavily on secondary sources. In this, Jones is no exception. In his study on Islamic mysticism, he frequently refers to Dabestan-e-Mazaheb (School of Religions) written by Mohsin Fani (born around 1516), a contemporary Persian historian. This work focuses on the inter-religious relations in Persia and India, and the author concluded that the religions and beliefs that emerged in this region were influenced by each other and thus mixed. On the advice of Jones, this book was later translated by his friend Francis Gladwin (d. 1813). Unfortunately, he did not complete the translation, and neither did his successor, David Shea (1777-1836). The task was taken on and completed by Anthony Troyer (1769-1865), and the Dabistan was finally published in Paris in 1843 and in London the following year.

Mohsin Fani introduced the term 'syncretic religion' (dîn-i-ilähî) in accordance with the tolerant religious philosophy instituted by the Mughal emperor Akbar (15561605). In 1582, Akbar the Great decided to unite all religions in his empire and put an end to interreligious strife and sectarianism. ${ }^{62}$ Akbar established the doctrine of din-iilāh (divine faith) as his last effort to unify his divided people, and Mohsen Fani's work was its primary source text. ${ }^{63}$ It is possible that Jones was influenced by the revolutionary ideas contained in this remarkable work. However, in using this book to learn about Islamic mysticism Jones may have chosen a work that lacked the necessary objectivity because it served an entirely different purpose.

Contemporary British orientalists were united in their praise of the astonishingly tolerant and progressive philosophy of the Dabestan. However, as later transpired, its author was a follower of the esoteric Zoroastrian movement of Azar Kayvan, a fact that led later scholars to discredit him as a reliable historical source. The work's immense popularity also reinforced many common orientalist stereotypes of Sufism, including its ostensible universality and its supposed lack of connection with orthodox Islam. ${ }^{64}$ The understanding of the universal dimensions of mysticism, whether Jewish, Christian, Islamic, or Hindu, led Jones to consider Sufism and other mystical traditions as being essentially one and the same. As a result of his comparative study, Jones concluded that all mystical doctrines and beliefs shared the same fundamental teachings. He wrote:

"From these principles flow a thousand metaphors and poetical figures, which abound in the farced poems of the Persians and Hindus, who seem to mean the

62 Mohsin Fani, The Dabistan or the School of Manners, trans. David Shea and Anthony Troyer, vol. iii (Paris, 1843), 220-21.

63 Khadija Sadia, “Akbar's Religious Reforms: Unifying Mortal Enemies” (Northern Illinois University, 2019), 22.

64 Carl W. Ernst, "The Dabistan and Orientalist Views of Sufism," in Sufism East and West: Mystical Islam and Cross-Cultural Exchange in the Modern World, ed. Jamal Malik and Saeed Z. Zarrabi (Leiden: Brill, 2019), 33-53. 
same thing in substance, and differ only in expression and their language differ in idiom." 65

Jones thus understood Sufi teachings as the result of an amalgamation of the Persian and Hindu traditions found in India. He, like many others before and after him, believed that the name 'Sufi' was derived from 'sopos' or șūf (Arabic for sheep's wool) which was the standard clothing of the Persian ascetics.

"The source of Sufi belief is as follows: in essence, the only thing that exists is God. The human soul is a splash of the form of God. Therefore, no matter how separated humans are at this time from God and are in the world, they will eventually return and unite with God. This moment of union will give birth to the greatest happiness and joy that man can think of. The highest happiness in this mortal world is none other than the readiness of the soul to leave the mortal body and prepare to unite with the immortal spirit. However, this can happen when humans distance themselves from all attachments to the external and have been able to live in the world without depending on the mortal. If worldly beauty can affect the soul, it is perfectly normal for spiritual and divine beauty to affect the soul to a greater extent and will cause spiritual intoxication... In such a situation, the soul cannot find words to describe divine nature and beauty, and instead, it uses the language of human love most likely to reveal divine beauty... this is an exotic and interesting religion in modern Persia, especially the one taught by Hafiz and Rumi. Vedanta thought and Indian poems are also like this. The thought system of the thinkers of these two nations is the same, since ancient times it has not changed. The many similarities between these religions and Sufism are evidence that supports our claim." ${ }^{\circ 6}$

Jones's authority in the field turned this idea into a widely accepted notion: Sufism had originated from India and Iran. In his desire to base Islamic mysticism on universal values that are shared by all religions, Jones effectively negated the relationship of Sufism with Islam. Unfortunately, this view has remained popular among British orientalists. For example, Cyprian Rice (1889-1966) stated that what is called mysticism in Islam stems exclusively from the Persian tradition. He argued that most Sufi works were only written in Arabic because Arabic was the common language of Muslim scholars at the time; the spiritual home of Sufism, however, was Persia. He wrote:

"It can be said that the Persians themselves used Arabic and used it as a means of expressing philosophical and scholarly thoughts after this language was only used by Arabs for poetry. This was Persia's revenge attempt for the humiliating defeat she suffered at the hands of the Arabs and as a result, Arabic was used for all religious and legal purposes. In this way, the poetic language and dogma of Sufism which they developed spread almost as widely as the popularity of the Qur'an itself, and the mystical understanding of love and Sufism has become an

65 Jones, “The Sixth Discourse on the Persian,”... 232.

66 Jones, "The Sixth Discourse on the Persian,"... 230-32.

Teosofia: Indonesian Journal of Islamic Mysticism, Vol. 10, No. 1, 2021 
alternative to the rigid and formal teachings of Islam. Thus, the Iranians may have lost to the Arabs on the battlefield, but they won on the field of mysticism." 67

Rice agreed that it was William Jones who had introduced Islamic mysticism into British orientalist circles. Although his Commentaries on Arabic Poetry published in 1774 could not find the necessary resonance at the time, his move did open British eyes to the Iranian world and its mystical dimensions. ${ }^{68}$ Jones' works, however, would eventually gain their place in the public discourse, and his ideas have been kept alive by British orientalists to this day. Among other orientalists who compared certain elements found in Sufism and Hinduism was Richard F. Burton (1821-1890). He suggested that Sindhi vernacular literature was tied to vernacular Sufism. ${ }^{69}$ Thus, the Western concepts of Sufism and Islam were consciously separated at the point of their emergence into and popularization through the discourse of the Orientalists.

Although Sufism has always been inextricably linked with the Qur' an and the Sunnah of the Prophet Muhammad and is understood by all Muslims as a sincere form of devotional practice and the science of divine realities and mystical knowledge, the orientalists re-interpreted it and made it part of an essentially anti-dogmatic (and therefore anti-Islamic) monistic or pantheistic movement.

\section{Conclusion}

From the discussion above, we can draw three conclusions. First, Sir William Jones made a major contribution to British orientalism by establishing a systematic approach to the study of the East within a single institution. In the following periods, these institutions not only nurtured the interest in the study of Eastern cultures and languages but also greatly enriched this academic field with their scholarly journal and monograph studies. Second, it can be agreed that Jones successfully introduced Sufi thought to the West, although in a very eclectic manner. Systematic expositions of Sufi thought, not to mention spiritual practices, were not included in his references, and his knowledge of Islamic mysticism was solely based on Persian poetry. Third, although Jones and his generation were clearly superior to the earlier generations of travelers and observes of Muslim cultures, they failed to arrive at an objective understanding of the spiritual knowledge and practice of the Sufis. Jones and his likes did not tap into the rich ocean of classical Sufi knowledge, but their successors later did-without regret.

67 Cyprian Rice, The Persian Sufis (London: George Allen \& Unwin, 1964), 9-11.

68 Rice, The Persian Sufis,... 14.

69 See Michel Boivin, "Knowledge, Sufism, and the Issue of a Vernacular Literature," in The Sufi Paradigm and the Makings of a Vernacular Knowledge in Colonial India (Cham: Springer International Publishing, 2020), 95-113, https://doi.org/10.1007/978-3-030-41991-2_4. 


\section{Bibliography}

Amirmiya, Saiyed Samirmiya. "Foundation of the Asiatic Society and the Discoveries of Cultural and Literary History of India." International Journal of Research and Analytical Reviews 6, no. 1 (2019): 139-41.

Arberry, Arthur John. An Introduction to the History of Sufism. London: Orient Longman, 1942.

- "Islamic Literature: Persian." In Near Eastern Culture and Society A Symposium on the Meeting of East and West, edited by T. Cuyler Youngs. Princeton: Princeton University Press, 1951.

—. Oriental Essays, Portraits of Seven Scholars. London: Curzon Press, 1960.

Avcıoğlu, Gemze Gizem. “Sa'di Sîrâzî’nin Hayat1, Eserleri ve Türk Edebiyatındaki Yeri." Istanbul Üniversitesi, 2018.

Biddulph, William. "The Travels of Certain Englishmen." In Early Modern Tales of Orient, edited by Kenneth Parker. London, New York: Routledge, 1999.

Boivin, Michel. "Knowledge, Sufism, and the Issue of a Vernacular Literature." In The Sufi Paradigm and the Makings of a Vernacular Knowledge in Colonial India, 95-113. Cham: Springer International Publishing, 2020. https://doi.org/10.1007/978-3-030-41991-2_4.

Bulut, Yücel. "Oryantalizmin Tarihsel Gelişimi Üzerine Bazı Değerlendirmeler." Marife Dergisi 3, no. 2 (2002): 13-38.

Cannon, Garland. The Life, and Mind of Oriental Jones. Cambridge: Cambridge University Press, 1991.

Ciutacu, Sorin. "Arabia in the Early Modern European Mind. Representations of Arabia in Early Modern European Maps." Analele Universităţii de Vest Din Timişoara. Seria Ştiinţe Filologice, no. 57 (2019): 139-44.

Davutoğlu, Ahmet. "Batıdaki İslam Çalışmaları Üzerine.” Marife 3, no. 2 (2002): 39_ 52. https://doi.org/10.5281/zenodo.3343235.

Demir, Serkan. “Akdeniz'de Korsanlar Ve Esirler Bağlamında Joseph Pitts Ve Esâretnâmesi.” Hacattepe Üniversitesi, 2020. http://hdl.handle.net/11655/22576.

Derin, Süleyman. İnggiliz Oryantalizmi ve Tasavvuf. Istanbul: Küre Yayınları, 2006.

—. "İngiliz Oryantalistlerinin Tasavvuf Araştırmalarına Katkıları." Türkiye Araştırmaları Literatür Dergisi 16, no. 21-32 (2018): 177-96.

Ernst, Carl W. "Commentary on Part I: Ambiguities and Ironic Reversals in the Categorization of Sufism." In Modern Sufis and the State, edited by Katherine 
Pratt Ewing and Rosemary R. Corbett, 73-78. West Sussex: Columbia University Press, 2019. https://doi.org/10.7312/ewin19574-007.

- Sufism: An Introduction to the Mystical Tradition of Islam. Boulder, Colorado: Shambhala Publication, 1997.

-. "The Dabistan and Orientalist Views of Sufism." In Sufism East and West: Mystical Islam and Cross-Cultural Exchange in the Modern World, edited by Jamal Malik and Saeed Z. Zarrabi. Leiden: Brill, 2019.

Fani, Mohsin. The Dabistan or the School of Manners. Translated by David Shea and Anthony Troyer. Vol. iii. Paris, 1843.

Foster, Sir William. An Account by Joseph Pitts of His Journey from Algiers to Mecca and Medina and Back. United Kingdom: Millwood, 1990.

Gholi, Ahmad. "Reiteration of Prophet Muhammad's Myths in Biddulph and Cartwright's Travelogues." Mediterranean Journal of Social Sciences 7, no. 1 (January 5, 2016): 251-58. https://doi.org/10.5901/mjss.2016.v7n1s1p251.

Jones, William. Al-Sirajiyah or the Muhammadan Law of Inheritance. Edited by Almeric Rumsey. London: Law Bookseller and Publisher, 1869.

. "An Essay on the Poetry of the Eastern Nations." In The Works of Sir William Jones, edited by Lord Teignmouth, 329-60. Cambridge: Cambridge University Press, 1807. https://doi.org/10.1017/CBO9781139506991.024.

-. "Histoire de Nader Chah." In The Works of Sir William Jones, edited by Lord Teignmouth, xi-xii. Cambridge: Cambridge University Press, 1807. https://doi.org/10.1017/CBO9781139507004.001.

—. "The Sixth Discourse on the Persian.” In Works, Vol. iv. London, 1807.

Kahraman, Kemal. “Jones William.” DIA. Istanbul, 2001.

Kalinowska, Anna. "An Englishman In-between Two Worlds: Robert Bargrave's Travel through East-Central Europe, 1652-1653." Studia Historyczne 61, no. 4 (244) (June 1, 2021): 45-54. https://doi.org/10.12797/SH.61.2018.04.03.

Khalil, Atif. Repentance and the Return to God: Tawba in Early Sufism. New York: Suny Press, 2018.

Khalil, Atif, and Shiraz Sheikh. "Sufism in Western Historiography: A Brief Overview." Philosophy East and West 66, no. 1 (2016): 194-217. https://doi.org/10.1353/pew.2016.0022.

Lawrence, Jonathan. "Building a Library: The Arabic and Persian Manuscript Collection of Sir William Jones." Journal of the Royal Asiatic Society 31, no. 1 (January 9, 2021): 1-70. https://doi.org/10.1017/S1356186320000607. 
Lewis, Bernard. British Contribution to Arabic Studies. Oxford: Oxford University Press, 1961.

Lord Dundonald, George Stephenson, Nelson, Napoleon, Captain Cook, George Washington, Walter Scott, et al. Famous Men, Being Biographical Sketches from Chamber's Miscellany. London: Chamber's Miscallany, 1892.

Nasir, Sari J. The Arabs and the English. London: Longman Group, 1976.

Nicholay, Nicolas de. The Navigations into Turkiye. Amsterdam: Theatrum Orbis, 1968.

Ockley, Simon. "Introduction." In The Improvement of Human Reason Exhibited in the Live of Hay Ibn Yaqzan. London, 1708.

Özen, Deniz. "Sûdî’nin Hâfız-1 Şirâzî Dîvânı Şerhi: 75a-99b Varakları Arası Transkripsiyonlu Metin-İnceleme.” Binali Yıldırım Üniversitesi, 2018.

Parker, Kenneth. "Introduction." In Early Modern Tales of Orient, A Critical Anthology. London: Routledge, 1999.

Rahman, F. “'Arad.” In Encyclopaedia of Islam, Second Edition, edited by P. Bearman, Th. Bianquis, C.E. Bosworth, E. van Donzel, and W.P. Heinrichs. Leiden: Brill, 2012. https://doi.org/10.1163/1573-3912.

Riach, Alan. "Odd Fellows: Alan Riach Examines the Colorful Work of William Lithgow and Thomas Urquhart." The National, April 7, 2017.

Rice, Cyprian. The Persian Sufis. London: George Allen \& Unwin, 1964.

Rosli, Ummi Nadhirah, and Noritah Omar. "References of Sexuality in Relation to the Prophet Muhammad (PBUH) in 17th-19th Century: Selected French and English Orientalist Travelogues." Arab World English Journal For Translation and Literary Studies 1, no. 4 (October 15, 2017): 68-82. https://doi.org/10.24093/awejtls/vol1no4.5.

Sadia, Khadija. “Akbar's Religious Reforms: Unifying Mortal Enemies.” Northern Illinois University, 2019.

Sağlık, Haci. "Kalenderî Bir Sûfî Olarak Baba Tâhirê Uryân.” E-Şarkiyat 10, no. 2 (May 30, 2018): 708-23. https://doi.org/10.26791/sarkiat.368830.

Uždavinys, Algis. "Sufism in the Light of Orientalism." Acta Orientalia Vilnensia 6, no. 2 (January 1, 2005): 14-125. https://doi.org/10.15388/AOV.2005.0.3966.

Watkin, Owen. "Sir William Jones (1746-1794) and Islamic Studies." University of Wales, 2013.

Yaman, Hikmet. "İsmi Olmayan Bir Hakikatten Hakikati Olmayan Bir İsme Varan Yolculuk." Akademiar Dergisi 1, no. 1 (2016): 15-48. 
Yıldırım, M. Ibrahim. "Abdullâh Hâtifî’nin Hayati Ve Bir Tarih Kaynaği Olarak Timurnâme'sinin Değeri." TÜRKI YAT MECMUASI 28, no. 2 (December 18, 2018): 231-54. https://doi.org/10.18345/iuturkiyat.497592. 